\title{
PERBEDAAN QIRA'AT DAN PENGARUHNYA DALAM ISTINBATH HUKUM
}

\author{
Halimah B. \\ Fakultas Syariah dan Hukum UIN Alauddin Makassar
}

\section{Abstract}

Qira' at is a school that is held by a qira' at priest who is different from the others in the pronunciation of the lafaz-lafaz al-Qur'an, and agrees with the narrations and paths thereof, both differences in the pronunciation of letters, the alms and the pronunciation of the shape.

Qira'at al-Qur'an is tawqify, which is sourced from the Messenger of Allah. not ijtihadi. The scholars set criteria as a standard for accepting the validity of the reading, that must be in accordance with the rules of A rabic, in accordance with the writing of one of the mani Usmani manuscripts and narrated with a valid sanad. On this basis the ulama concludes 6 (six) qira'at levels; namely: qira'at muatawatir, masyhur, ahad, syaz, muwdhu and mudraj.

The difference in qira' at does not always lead to changes in the meaning it contains. Likewise, in legal matters, it sometimes affects legal differences and sometimes does not affect the differences in the law imposed.

Keywords: Qira'at al-Qur'an, Istinbath Law.

\section{A. PENDAHULUAN}

Perbedaan bacaan al-Qur'an sudah ada sejak awal, masing-masing sahabat memegang teguh qira'at yang diterima dari Rasulullah saw. yang mungkin berbeda dari yang lain. ${ }^{1}$ Di dalam menerima bacaan al-Qur'an ada yang secara langsung dari Nabi saw. dan ada yang mengambil bacaan imam

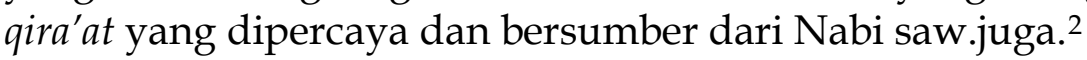

Dalam keadaan demikian, maka timbullah perbedaan qira'at yang diterima oleh tabi'in dan tabi'tabi'in. Demikianlah keadaannya sampai ke tangan para ulama yang mengkhususkan dirinya untuk mempelajari qira'at serta menyebarluaskannya, yakni terdiri dari qira'at sab'ah, qira'at 'asyarah, qira'at sab'ah 'asyarah.

Sehubungan dengan ini, 'Abd al-Hadi al-Fadl menyatakan bahwa sesungguhnya qira'at al-Qur'an bersumber dari Nabi saw., para sahabat meriwayatkan dari Nabi saw., dan para tabi'in meriwayatkan dari sahabat. Selanjutnya kaum muslimin meriwayatkannya pula dari generasi ke generasi berikutnya. Penyampaiannya seperti penyampaian al-Hadits. ${ }^{3}$ Dengan

\footnotetext{
${ }^{1}$ Muhammad 'Abdullah Diraz, Madkal Ila' al-Qur'an al-Karim' Aradun Tarikhiyyun Tahliliyun Maqarin (Kuwait: Dar al-Kalam, 1987), Cet.2, h. 42.

2 Muhammad 'Abdullah Diraz, Madkal Ila' al-Qur'an al-Karim' Aradun Tarikhiyyun Tahliliyun Maqarin, 413.

3 'Abd al-Hadi al-Fadli, al-Qira'at al-Qur'aniyah, (Beyrut: Dar al-Majma' al'Ilm, 1979), h.63. h.91.
} 
demikian, jelaskah bahwa qira'at al-Qur'an adalah bersifat tawqifi, bukan bersifat ijtihadi.

Perbedaan qira'at ditemukan dalam beberapa baik ayat hukum maupun lainnya, berbeda cara pengucapan lafaz-lafaz al-Qur'an dari segi hurufhurufnya, harakatnya dan bentuknya. Karena itu sangat urgen untuk diteliti secara secara mendalam bacaan yang sesuai dengan petunjuk Rasulullah saw. yang bersifat tauqiy, khususnya ayat-ayat hukum untuk mengetahui bagaimana pengaruh perbedaan qira'at terhadap penetapan (istinbath) hukum.

\section{B. PEMBAHASAN}

\section{Pengertian Qira'at.}

Secara etimologi lafaz qira'at (قرأة) adalah bentuk masdar dari akar kata (قرأ) yang berarti bacaan. ${ }^{4}$ Dari sini tampak bahwa kata qira'at memiliki akar kata yang sepadan dengan al-Qur'an.

Adapun secara terminologi (istilah) pengertian qiraat dikemukakan para pakar ulum al-Qur'an sebagai berikut:

1. Badar al-Din al-Zarkasyi mengemukakan bahwa qira'at yaitu perbedaan lafaz-lafaz al-Qur'an, baik menyangkut huruf-hurufnya maupun cara pengucapan huruf-huruf tersebut, seperti takhfif atau tasykil dan lain-lain. ${ }^{5}$

2. Abdul Hadi al-Fadli berpendapat qira'at yaitu suatu ilmu untuk mengetahui cara pengucapan lafaz-lafaz al-Qur'an, baik yang disepakati maupun yang diperselisihkan oleh para ahli qira'at, baik membuang huruf (hafz) atau menetapkan huruf (isbat), memberikan harakah (tahrik), memberikan tanda sukun (taskin), memisahkan huruf (fashl), menyambung huruf (washl), menggantikan huruf (ibdal) dan lain-lain yang diperoleh melalui indera pendengaran. ${ }^{6}$

3. Menurut al-Zarqaniy, qira'at suatu aliran bacaan al-Qur'an yang diperpegangi oleh Imam qira'at berbeda dengan qira'at lainnya dalam pengucapan al-Qur'an, sepakat dalam riwayat-riwayat dan cara-cara meriwayatkannya, baik dari segi pengucapan huruf-huruf maupun pengucapan dalam berbagai bentuk bacaannya. ${ }^{7}$

Bertolak dari pendapat para ulama diatas, dapat ditarik kesimpulan bahwa qira'at adalah suatu aliran yang diperpegangi oleh imam qira' at berbeda

${ }^{4}$ Manna Khalil al-Qattan, Mabahis fi 'Ulum al-Qur'an (Beirut: Mansyurat al-'Asr al-Hadits, 1973), h. 170. Muhammad 'Abd al-'Azim al-Zarqani, Manahil al-Irfan fi 'Ulum al-Qur'an, Juz I, (Beyrut: Dar al-Fikr, 1988), h. 412.

${ }^{5}$ Badr al-Din Muhammad al-Zarkasyi, al-Burhan fi 'Ulum al-Qur'an, Juz 1 (Mesir: 'Isa al-Bab alHalabi, t.th), h. 38. Al-Subhi al-Salih, Mabahis fi 'Ulum al-Qur'an (Mesir: Dar al-'Ilm li al-Malayin, 1988), h. 108.

6 'Abd al-Hadi Fadli, al-Qira'at al-Qur'aniyah, h.63.

7 Muhammad 'Abd al-'Azim al-Zarqani, Manahil al-'Irfan fi Ulum al-Qur'an, 412. 'Abduh Zulfidar Akaha, al-Qur'an dan Qira'at (Jakarta: Pustaka al-Husna, 1996), h.117. 
dengan imam qira'at lainnya dalam pengucapan lafaz-lafaz al-Qur'an menyangkut huruf-huruf, harakat dan berbagai bentuknya.

\section{Sejarah Perkembangan Qira'at al-Qur'an.}

Al-Qur'an sebagai kalam Allah yang diturunkan kepada Nabi Muhammad saw. melalui perantaraan Jibril yang berfungsi sebagai penyampai sekaligus pembaca di hadapan Nabi saw. Nabi saw. menerima dari Jibril dan selanjutnya meneruskan kepada sahabat dan kaum muslimin. Setiap kali Nabi saw. menerima ayat yang diturunkan dibacakan di hadapan sahabat dan menyuruh untuk menulis sehingga sempurnalah al-Qur'an dalam tempo kurang lebih dua puluh tiga tahun. Oleh karena itu banyak sahabat yang menghapal al-Qur'an pada masa Nabi saw.

Bacaan-bacaan yang masyhur dari sahabat itulah yang diambil oleh tabi' in pada setiap waktu dan tempat. ${ }^{8}$ Bentuk bacaan yang banyak itu semuanya dijamin kebenarannya karena sanadnya bersambung sampai kepada Nabi saw. Dengan demikian jelaslah bahwa qira'at al-Qur'an adalah tawqifi bukan ikhtiyari, ${ }^{9}$ sekalipun terjadi perbedaan dalam pengucapan beberapa bunyi suara di antara qira'at yang satu dengan qira'at yang lain dan tetap dinilai sebagai suatu yang berasal dari wahyu. ${ }^{10}$

Dalam perkembangan selanjutnya, perbedaan bacaan yang sebelumnya masih dalam kerangka tawqifi, ternyata tidak terlepas dari pencemaran. Hal ini disebabkan karena meluasnya daerah kekuasaan Islam dan juga pengiriman salinan mushaf 'Usmaniy ke beberapa daerah pada waktu itu belum diberi tanda titik dan harakat. Kebijakan dari 'Usman ibn Affan tersebut adalah untuk menyeleksi bacaan yang berkembang di kalangan masyarakat agar sesuai dengan yang diajarkan oleh Rasulullah saw. ${ }^{11}$ Akibat tersebut di atas, maka terbukalah peluang perbedaan persepsi dalam cara membaca al-Qur'an.

Perbedaan bacaan antara yang satu dengan yang lainnya semakin lama semakin bertambah luas, sehingga sulit untuk dikenal bacaan mana saja yang bisa dipertanggung jawabkan. ${ }^{12}$ Dalam situasi seperti inilah, maka sebahagian ulama bangkit dan berusaha untuk meneliti dan menyeleksi versi bacaan dengan menetapkan beberapa kriteria dan rukun-rukun qira'at yang dapat diterima kesahihannya. Secara umum pedoman yang dipakai dalam meneliti dan menyeleksi qira' at bilamana memenuhi kriteria berikut ini:

- Sesuai dengan kaidah bahasa Arab

- Sesuai dengan tulisan pada salah satu mushaf 'Usmany.

8 'Abd al-Hadi al-Fadli, al-Qira'at al-Qur'aniyah, h. 17.

${ }^{9}$ Muhammad Badr al-Din al-Zarkasyi, al-Burhan fi 'Ulum al-Qur'an, h.321.

${ }^{10}$ Muhammad Badr al-Din al-Zarkasyi, al-Burhan fi 'Ulum al-Qur'an, h. 321.

11 Abu al-A'la al-Maududi, The Meaning of the Qur'an (New Delhi: Maktabat al-Jama'ah EIslami Hind, 1972).

12 Muhammad 'Ali al-Sabuni, al-Tibyan fi 'Ulum al-Qur'an, (terj) oleh Ramli Abdul Wahid, Pengantar Ilmu-Ilmu al-Qur'an (Surabaya: al-Iklas, 1983), h. 437. 
- $\quad$ Di riwayatkan dengan sanad yang sahih. ${ }^{13}$

\section{Macam-Macam dan Tingkatan Qira'at.}

1. Dari segi jumlah qira'ah terbagai 3 (tiga) berikut:

a. Qira'ah Sab'ah (qira'at tujuh) yang dinisbatkan kepada 7 (tujuh) imam qira'at yang terkenal yaitu: Nafi, 'Ashim, Hamzah, 'Abdullah ibn 'Amer, 'Abdullah ibn Katsir, Abu 'Amru ibn al'Ala' dan 'Ali alKassa'i.

b. Qira'ah 'Asyarah (sepuluh), qira'at yang dinisbatkan kepada imam qira'at tujuh di atas ditambah dengan 3 (tiga) imam qira'at yaitu: Abu Ja'far, Ya'qub dam Khalaf.

c. Qira'at 'Arba'ah yaitu imam qira'at yang sepuluh ditambah dengan 4 (empat) imam qira'at yaitu: Hasan al-Basri, Ibn Muhaisin, Yahya alYazidi dan al-Syambuzi. ${ }^{14}$

2. Dari segi sanad qira'at terbagi 5 (lima) macam/tingkatan berikut: 15

a. Mutawatir, yaitu qira'at yang diriwayatkan oleh banyak orang (periwayat) yang tidak mungkin sepakat untuk berdusta dan sanadnya bersambung sampai kepada Rasulullah saw., termasuk dalam kategori ini menurut jumhur ulama adalah qira'at sab'ah. ${ }^{16}$ Contoh QS.al-Fatihah/1:4 ( مالك يوم الدين ). Imam 'Ashim membacanya dengan tanwin dhammah pada huruf kaf, sedang yang lain membaca sebagaimana dalam teks.

b. Masyhur, yaitu qira'at sahih sanadnya sampai kepada Rasulullah saw., tetapi tidak mencapai derajat mutawatir, hanya diriwayatkan oleh seorang atau beberapa orang yang adil dan tsiqah, sesuai dengan bahasa Arab dan sesuai dengan rasm 'Usmani serta terkenal dikalangan ahli qira'at. Qira'at macam ini dapat digunakan dan boleh dibaca pada waktu shalat atau diluar shalat. Adapaun bacaan alQur'an pada tingkatan ini adalah bacaan yang dibangsakan kepada tiga imam qira'at, yaitu Abu Ja'far ibn Qa'qa al-Madani, Ya'qub al-

13 Ibn al-Jaziri, al-Nasyr fi al-Qira'at al-'Asyr, Juz 1 (Mesir: Dar al-Fikr, t.th.), h. 17. 'Abd alSabur Syahir, Qira'at al-Qur'aniyah fi Dani 'Ilm al-Lughah al-Hadith (Kairo: Dar al-'Ilm, 1996), h. 257. Muhammad 'Abd al-'Azim al-Zarqani, Manahil al-'Irfan fi 'Ulum al-Qur'an, Juz 1, h. 418.

${ }^{14}$ Muhammad 'Abd al-'Azim al-Zarqani, Manahil al-'Irfan fi 'Ulum al-Qur'an, Juz 1, h. 416-417. Jalal al-Din al-Suyuti, al-Itqan fi 'Ulum al-Qur'an, Juz 1, (Kairo: Dar al-Hadith, 2006), h.225. Nur alDin 'Atar, 'Ulum al-Qur'an al-Karim (Damaskus: al-Sabal, 1996), h. 150-151.

15 Muhammad 'Abd al-'Azim al-Zarqani, Manahil al-'Irfan fi 'Ulum al-Qur'an, Juz 1, 430-431, Jalal al-Din al-Suyuti, al-Itqan fi 'Ulum al-Qur'an, Juz 1, h.234-235. Muhammad Badr al-Din alZarkasyi, al-Burhan fi 'Ulum al-Qur'an, h.318. Nur al-Din 'Atar, 'Ulum al-Qur'an al-Karim, h. 148-149.

${ }^{16}$ Muhammad 'Abd al-'Azim al-Zarqani, Manahil al-Irfan fi 'Ulum al-Qur'an, h. 430. Jalal al-Din al-Suyuti, al-Itqan fi 'Ulum al-Qur'an, h. 234. 
Khadrami, dan Khalaf ibn Hisyam al-Bazzar. ${ }^{17}$ Contoh QS. alFatihah/1: 7 (عليهم ولا الضالين). Ya'qub al-Hadrami membacanya dengan dhammah pada huruf mim tersebut.18 Sedangkan yang lain membacanya seperti yang tertulis dalam teks.

c. Ahad, yaitu qira'at yang sahih sanadnya tetapi menyalahi (tidak sesuai) dengan rasm 'Usmani dan kaedah bahasa Arab serta tidak terkenal seperti kedua tingkatan qira'at di atas. Qira'at macam ini tidak dapat digunakan dan tidak wajib menyakininya. Contoh riwayat Ibn 'Abbas mengatakan bahwa Rasulullah saw. membaca لقد جاّكمم رسول من أنفسكم(QS. al-Tawbah/9: 128) dengan memfathahkan huruf $f a^{\prime}$ pada lafaz ( أنفسكم) padahal qira'at yang benar dibaca dhammah. Contoh lain متكئين على مan diriwayatkan Abu Bakrah bahwa Nabi saw. membaca متكئين على ) (QS.al-Rahman/55: 76), dibaca) (رفرف خضر و عبقري حسان)

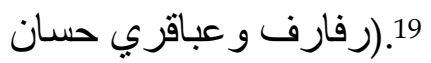

d. Syaz, yaitu qira'at yang sanadnya cacat (tidak sahih) dan tidak bersambung sanadnya kepada Rasulullah saw. Qira'at ini tidak bisa dijadikan pegangan dalam membaca al-Qur'an. Contoh lain, Ibn Sumaifi membaca QS. Yunus/10: 92 فاليوم ننجيك ببدنك لتكون لمن خلقكالك

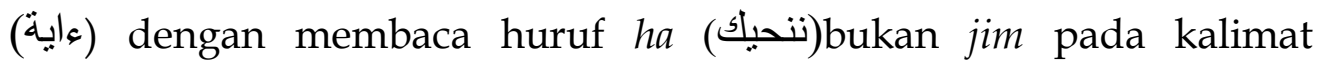

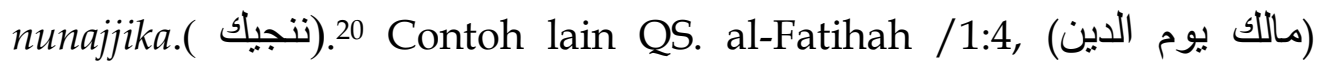

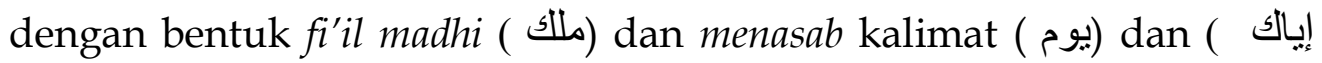
(إيالك يعبد dibaca).21

e. Maudhu, yaitu qira'at yang tidak ada asalnya, dibuat-buat dan dinisbatkan kepada seseorang tanpa dasar. Qira'at ini juga tidak diakui keabsahannya. Contoh qira'at Muhammad Ibn Ja'far al-Khuza'i yang dinisbatkan kepada Abu Hanifah dalam QS. Fathir/35: 28 ( إنما

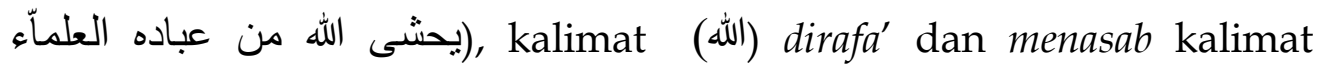

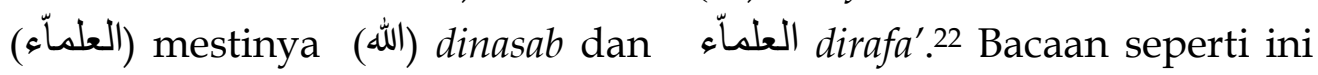
mengubah makna karena subyek menjadi obyek yakni dapat berarti

\footnotetext{
${ }^{17}$ Jalal al-Din al-Suyuti, al-Itqan fi 'Ulum al-Qur'an, h. 234. Hasanuddin AF, Anatomi al-Qur'an: Perbedaan Qira'at dan Pengaruhnya Terhadap Istinbath Hukum dalam al-Qur'an (Jakarta: PT.Raja Grafindo Persada, 1995), h.141. Muhammad 'Abd al-'Azim al-Zarqani, Manahilal-'Irfan fi 'Ulum alQur'an,h, h.430.

18 'Abduh Zulfidar Akaha, al-Qur'an dan Qira'at, h, 125.

${ }^{19}$ Muhammad 'Abd al-'Azim al-Zarqani, Manahil al-'Irfan fi 'Ulum al-Qur'an, 430. Jalal al-Din al-Suyuti, al-Itqan fi 'Ulum al-Qur'an, h, 234-235.

${ }^{20}$ Manna Khalil al-Qattan, Mabahis fi 'Ulum al-Qur'an, h.257.

${ }^{21}$ Jalal al-Din al-Suyuti, al-Itqan fi 'Ulum al-Qur'an, h. 235.

${ }^{22}$ Al- Subhi al-Salih, Mabahis fi 'Ulum al-Qur'an, h.256.
} 
Allah takut kepada ulama, padahal mestinya ulama takut kepada Allah.

f. Mudraj, yaitu qira'at di dalamnya terdapat tambahan qira'at sebagai penafsiran al-Qur'an seperti qira'at Sa'ad ibn Abi Waqqas (منه أخ أو أخت dengan menambah sن أم (من أم) pada akhir kalimat tersebut. Contoh

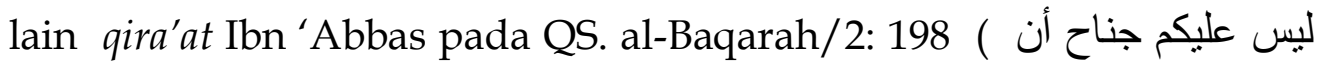

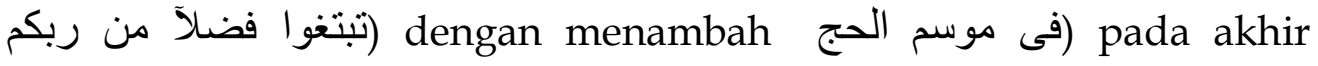
kalimat tersebut, disisipkan ke dalam ayat. ${ }^{23}$ Tambahan-tambahan kalimat yang terdapat pada akhir ayat atau pada pertengahan ayat bukan ayat.

Jadi macam-macam dan tingkatan qira'at di atas yang termasuk bacaan yang sahih dan boleh diamalkan bacaannya adalah qira'at mutawatir dan masyhur, sementara qira'at ahad, syaz, maudhu' dan mudraj adalah yang tidak sahih dan tidak boleh diamalkan bacaannya,

\section{Pengaruh Perbedaan Qira'at dalam Istibnath Hukum.}

Berbagai riwayat hadits Nabi saw. diterangkan bahwa al-Qur'an diturunkan dalam tujuh huruf (al-ahruf al-sab'ah). ${ }^{24}$ Hadits-hadits Nabi saw. tentang al-ahruf al-sab'ah menjadi pemicu adanya perbedaan pendapat di antara para ahli yang melahirkan interpretasi tentang adanya perbedaan qira'at alQur'an. Bervariasinya qira'at yang sahih ini mengandung banyak faedah antara lain; menunjukkan betapa terpeliharanya dan terjaganya kitab Allah dari perubahan dan penyimpangan, walaupun mempunyai sekian banyak bacaan yang berbeda-beda. Begitu pula meringankan umat Islam dan memudahkan mereka membaca al-Qur'an dan sebagai bukti kemukjizatan al-Qur'an dari segi kepadatan makna (ijaznya), karena setiap qira'at menunjukkan sesuatu hukum syara' tertentu tanpa pengulangan lafaz. ${ }^{25}$

Dari penjelasan di atas dengan beberapa contoh bacaan al-Qur'an dengan beberapa versi meliputi perbedaan dalam pengucapan harakat, huruf, dan bentuk kata. Susunan kalimat dan penambahan maupun pengurangan kata, maka didasarkan pengamatan terhadap beberapa sumber yang ada, ternyata ada perbedaan qira'at tersebut tidak selamanya menimbulkan pengubahan arti yang dikandungnya. Karena perbedaan bacaan tidak selamanya membawa dampak pada arti kata yang dikandungnya. Demikian pula halnya dengan masalah hukum yang dikandungnya. Jadi adakalanya berpengaruh terhadap perbedaan hukum dan adakalanya tidak berpengaruh terhadap perbedaan hukum yang diintinbatkan.

23 Jalal al-Din al-Suyuti, al-Itqan fi 'Ulum al-Qur'an, h.235. Manna Khalil al-Qattan, Mabahis fi 'Ulum al-Qur'an, h.257.

${ }^{24}$ Muhammad 'Abd al-'Azim al-Zarqani, Manahil al-Irfan fi 'Ulum al-Qur'an, Juz 1, h. 139. AlSubhi al-Salih, Mabahis fi 'Ulum al-Qur'an, h. 119.

${ }^{25}$ Jalal al-Din al-Suyuti, al-Itqan fi 'Ulum al-Qur'an, Juz 1, h. 245-246. 
1. Perbedaan qira'at yang berpengaruh terhadap istinbath hukum. Contoh firman Allah dalam QS. al-Baqarah/2: 222 :

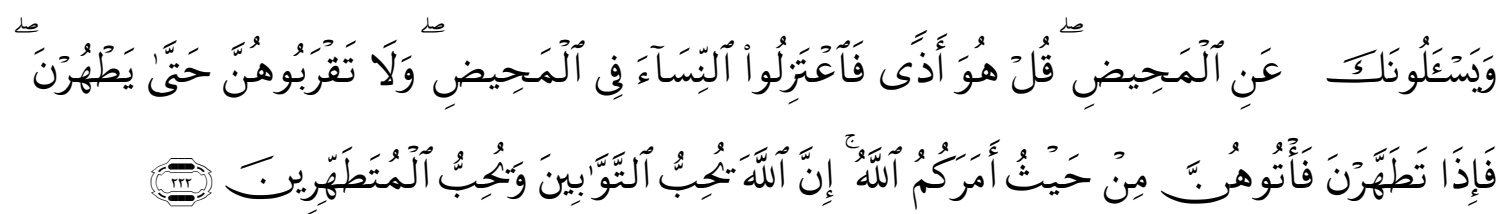

Terjemahnya :

Mereka bertanya kepadamu tentang haid. Katakanlah haid itu adalah kotoran. Oleh sebab itu hendaklah menjauhkan diri dari wanita itu waktu haid; dan janganlah kamu mendekati mereka, sebelum mereka suci. Apabila mereka telah suci, maka campurilah mereka itu di tempat yang diperintahkan Allah kepadamu. Sesungguhnya Allah menyukai orang-orang yang taubat dan menyukai orang-orang yang mensucikan diri. ${ }^{26}$

Ayat di atas adalah larangan Allah terhadap suami untuk berhubungan intim dengan istrinya yang sementara haid.

Dalam ayat tersebut di atas terdapat perbedaan bacaan pada lafaz yathhurna (يطهرن) dengan bacaan takhfif yakni disukun huruf tho (b) dhamma

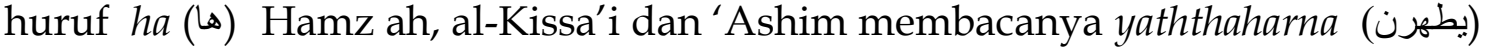
bertasydid huruf tho ( $b$ dan ha (ه) serta menasab kedua huruf tesebut (b dan ها ). Sedangkan, Ibn Kathir, Nafi', Abu 'Amr, Ibn 'Amir menurut riwayat Hafsah membacanya seperti yang tertulis dalam teks tersebut. ${ }^{27}$

Perbedaan bacaan dari ayat di atas menimbulkan perbedaan hukum yang dikandungnya. Bacaan pertama dengan bacaan takhfif lafaz (يطهرن) bahwa seorang suami haram hukumnya untuk berhubungan intim dengan istrinya dalam keadaaan haid sampai berhenti haidnya dan mandi. Pandangan ini diperpegangi oleh Imam Malik, Imam Syafi'i dan Ahmad.

Bacaan kedua dengan tasydid lafaz (يطهرن), menurut Imam Abu Hanifah bahwa yang dimaksud dari ayat di atas adalah larangan kepada suami untuk berhubungan intim sampai istrinya suci, artinya berhenti darah haid. Dengan demikian, suami diperbolehkan untuk berhubungan intim dengan istrinya karena telah berhenti haid, meskipun belum mandi. ${ }^{28}$

Jika dua qira'at berbeda makna, tetapi tidak jelas kontradiksi antara keduanya, sedangkan keduanya mengacu kepada hakikat yang sama, maka kedua qira'at itu saling melengkapi. ${ }^{29}$ Perbedaan kedua qira' at tidak kontradiksi dari segi makna, keduanya termasuk qira'at sahih. Perbedaan yang ditimbulkan terhadap perbedaan istinbath hukum di sini hanya perbedaan dari wajib

${ }^{26}$ Kementerian Agama RI, al-Qur'an dan Terjemahnya (Jakarta: PT. Sinergi Pustaka Indonesia, 2012), h.54.

${ }^{27}$ Ibnu Mujahid, Kitab al-Sab 'at fi Qira'at (Mesir: Dar al-Ma'arif,t.th), h.182. Muhammad 'Ali alSabuni, Rawai 'u al-Bayan Tafsir Ayat al-Ahkam min al-Qur'an, Juz 1, (Beyrut: Alim al-Kutub, 1986), h. 295.

28 Muhammad 'Ali al-Sabuni, Rawai'u al-Bayan Tafsir Ayat al-Ahkam min al-Qur'an, Juz 1, h.301. Hasanuddin, AF, Anatomi al-Qur'an: Perbedaan Qira'at dan Pengaruhnya Terhadap Istinbath Hukum dalam al-Qur'an, h.203.

${ }^{29}$ Salman Harun, Kaidah-Kaidah Tafsir: Bekal Mendasar untuk Memahami Makna al-Qur'an dan Mengurangi Kesalahan Pemahaman, Cet. I (Jakarta: QAF, 2017), h.71 
mandi setelah berhenti haid dan boleh saja sebelum mandi jika sudah berhenti haid. Dengan demikian mencermati perbedaan pandangan ulama memberi kesan kedua pandangan yang berbeda itu dapat dikompromikan yakni bahwa suami haram menggauli istrinya yang sedang haid sampai berhenti dari haidnya.

Contoh lain dalam QS. al-Maidah /5: 6, berikut:

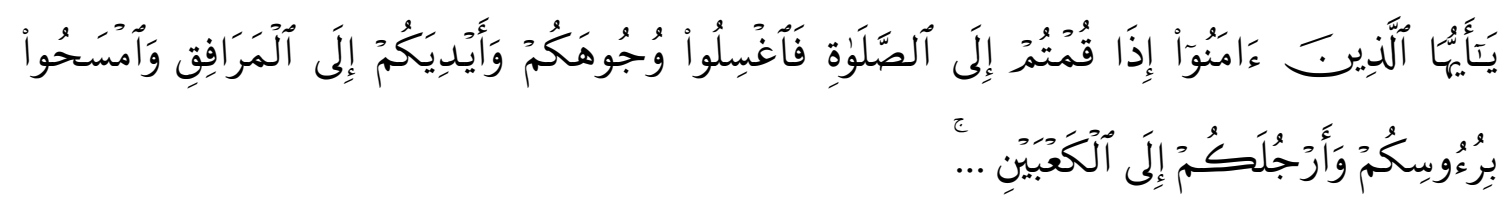

Terjemahnya:

Hai orang-orang yang beriman, apabila kamu hendak mengerjakan shalat, Maka basuhlah mukamu dan tanganmu sampai dengan siku, dan sapulah kepalamu dan (basuh) kakimu sampai dengan kedua mata kaki...30

Kata (أرجلكم) dinasabkan dan dihafadkan (dikasrah). Jumhur membaca sesuai dengan teks yakni dinasabkan huruf lam. Jika dinasab huruf lam maka ia ma'thuf dari lafaz (وجو هكم) yakni basuhlah mukamu, kedua tanganmu dan kakimu. Hal ini terdapat penjelasan tentang hukum membasuh kaki, yakni wajib membasuh kaki sampai kedua mata kaki sebagaimana wajibnya membasuh muka, kedua tangan sampai kedua siku. Hamzah dan Abu 'Amer membaca wa arjulikum (أرجلكم) dikasrah huruf lam. berarti ia ma'thuf dari lafaz ( yakni menjelaskan hukum menyapu kaki dan sepatu (sepatu khuf). ${ }^{31}$ Ibn al-Anbari berpendapat bahwa kata arjul dita'khirkan sesudah dari kata alru'us adalah 'athaf nusuq di kasrah karena 'athaf dari yang paling dekat yakni frase ru'usikum wa arjulikum. ${ }^{32}$

Berdasarkan uraian dari pandangan para ulama dan imam qira'at bahwa perbedaan qira'at tersebut tidak mengubah arti yang dikandungnya, Namun menimbulkan pengaruh terhadap perbedaan hukum yang diistinbathkan, yakni bacaan pertama wajib membasuh kaki sampai kedua mata kaki sebagaimana wajibnya membasuh wajah dan kedua tangan sampai kedua siku. Sementara bacaan kedua wajib menyapu kaki (sepatu khuf )sebagaima wajibnya menyapu sebahagian kepala.

Demikian penafsiran qira'at (لامستم النسآ ) dalam menetapkan salah satu yang membatalkan wudhu sebagaimana disebutkan dalam QS. al-Nisa'/4: 43 berikut:

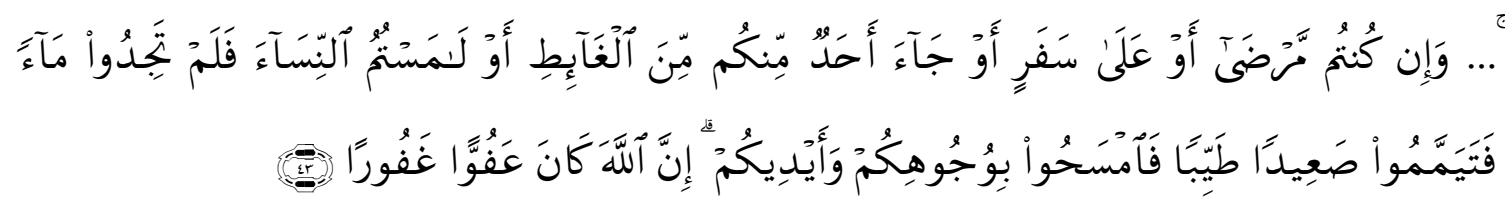

${ }^{30}$ Kementerian Agama RI, al-Qur'an dan Terjemahnya, h. 158.

${ }^{31}$ Muhammad 'Ali al-Sabuni, Rawai 'u al-Bayan Tafsir Ayat al-Ahkam min al-Qur'an, Juz 1, h. 533-534. Manna Khalil al-Qattan, Mabahis fi 'Ulum al-Qur'an, h. 258.

${ }^{32}$ Muhammad 'Ali al-Sabuni, Rawai'u al-Bayan Tafsir Ayat al-Ahkam min al-Qur'an, Juz 1, h. 534 


\section{Terjemahnya:}

... dan jika kamu sakit atau sedang dalam musafir atau datang dari tempat buang air atau kamu telah menyentuh perempuan, kemudian kamu tidak mendapat air, Maka bertayamumlah kamu dengan tanah yang baik (suci); sapulah mukamu dan tanganmu. Sesungguhnya Allah Maha Pema'af lagi Maha Pengampun. ${ }^{33}$

Terdapat perbedaan qira'at pada lafaz (لامستم النساًء). Ibn Kathir, Nafi', 'Asim, Abu Amer dan Ibn 'Amir membaca (لامستم النساء ), sedangkan Hamzah

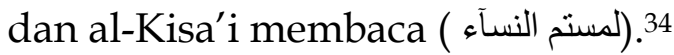

Perbedaan qira'at dalam ayat tersebut menimbulkan perbedaan terhadap istinbath hukum .Para ulama berbeda pendapat tentang makna (لامستم النساًء). 'Ali, Ibnu 'Abbas, al-Hasan berpendapat bahwa yang dimaksud al-lams adalah al-jima' (bersetubuh) yaitu mazhab Abu Hanifah. Hal ini memberi kesan bahwa menurut Abu Hanifah bersentuhan laki-laki dan perempuan yang bukan muhrim tidak membatalkan wudhu'. Sementara Ibnu Mas'ud, Ibnu 'Umar, alSya'bi berpendapat bahwa yang dimaksud dengan al-lam dalam ayat ini adalah menyentuh dengan tangan (الس باليد) yakni penganut mazhab al-Syafi'i. Dengan demikian hukum bersentuhan laki-laki dan perempuan yang bukan muhrim membatalkan wudhu. Imam Malik berpendapat bahwa batal wudu' apabila bersentuhan dengan perempuan yang bukan muhrim yang menyebabkan timbulnya syahwat, , tetapi jika tidak menimbulkan syahwat maka tidak membatalkan wudhu. ${ }^{35}$

Suatu pendapat menyatakan bahwa yang dimaksud dengan (لامستم النسآء) adalah menyentuh perempuan dengan tangan, sehingga hukumnya membatalkan wudhu'. Sedangkan maksud dari (لمستم النسأء) adalah berjima' dengan perempuan, sehingga hukumnya tidak membatalkan wudhu'. Menurut Ibnu Jarir al-Thabari bahwa pendapat yang paling utama dari kedua pandangan tersebut adalah pendapat yang mengartikan لمستم النسآء dengan berjima' tidak ada arti lain dari arti al-lams. Hal ini didasarkan pada sebuah hadits riwayat 'Aisyah yang menceritakan bahwa Rasulullah saw pernah mencium salah seorang istrinya sebelum berangkat sholat tanpa berwudhu lagi. ${ }^{36}$ Karena itu berdasarkan hadits tersebut memberi kesan bahwa yang membatalkan wudhu' adalah al-jima' (bersebutuh), dan menyentuh perempuan dengan tangan tidak membatalkan wudhu'.

Mencermati pendapat para ulama dapat disimpulkan bahwa lafaz (اللمس)

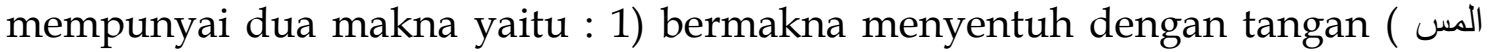
(باليد). 2) bermakna al-jima' (الجماع) yakni bersetubuh. Apabila merujuk ke makna pertama, maka bersentuhan laki-laki dan perempuan yang bukan muhrim

${ }^{33}$ Kementerian Agama RI, al-Qur'an dan Terjemahnya, h. 125.

${ }^{34} \mathrm{Abu}$ 'Abdillah Muhammad ibn Ahmad al-Qurtubi, al-Jami' li Ahkam al-Qur'an, Juz V (Beyrut: Dar al-Kutub al-'Ilmiyah, t.th), h. 223. Muhammad 'Ali al-Sabuni, Rawai'u al-Bayan Tafsir Ayat alAhkam min al-Qur'an, Juz 1, h. 481.

${ }^{35}$ Muhammad 'Ali al-Sabuni, Rawai'u al-Bayan Tafsir Ayat al-Ahkam min al-Qur'an, Juz 1, h. 487.

${ }^{36}$ Abu Ja'far Muhammad Ibn Jarir al-Thabari, Jami ‘ al-Bayan fi Ta’wil al-Qur'an, Juz V (Beyrut: Dar al-Kutub al-'Ilmiyah, 1978), h. 100. 
membatalkan wudhu'. Dan apabila merujuk ke makna yang kedua, maka bersentuhan laki-laki dan perempuan tidak membatalkan wudhu. Hal ini juga dapat dipahami bahwa makna pertama (المس باليد) adalah makna hakikinya dan (الجماع) adalah makna majazi.

2. Perbedaan qira'at yang tidak berpengaruh dalam istinbath hukum. Contoh firman Allah dalam QS. al-Ahzab/33: 49 berikut:

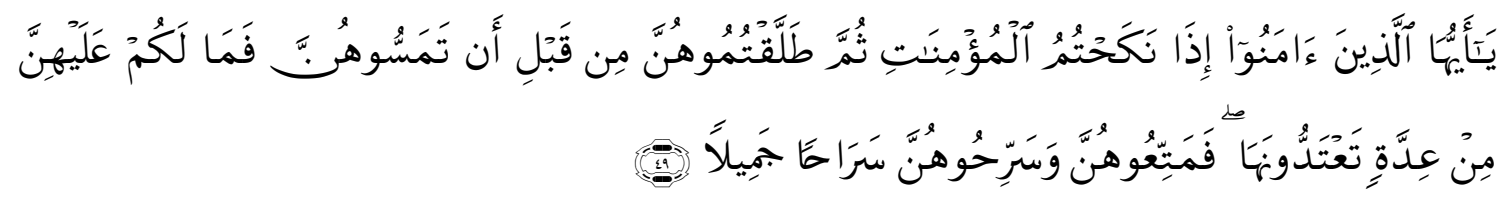

Terjemahnya:

Hai orang-orang yang beriman, apabila kamu menikahi perempuan- perempuan yang beriman, kemudian kamu ceraikan mereka sebelum kamu mencampurinya Maka sekalisekali tidak wajib atas mereka 'iddah bagimu yang kamu minta menyempurnakannya. Maka berilah mereka mut'ah dan lepaskanlah mereka itu dengan cara yang sebaikbaiknya. ${ }^{37}$

Ayat di atas menjelaskan bahwa seorang istri yang diceraikan oleh suaminya sebelum digauli (disetubuhi), maka tidak ada masa 'iddah baginya. Masa 'iddah adalah masa menunggu seorang istri yang telah diceraikan suaminya, dalam masa itu istri tidak dibolehkan menikah dengan laki-laki lain.

Dalam ayat di atas terdapat perbedaan bacaan dari lafaz ( من قبل أن (تمسو هن). Jumhur membaca sesuai dengan teks. Sementara Hamzah dan al-Kisa'i membaca min qabli 'an tumasahunna (من قبل أن تماسهن) dengan menambahkan huruf alif dan di dhammah huruf $t a(ت)$.

Kata lain dalam ayat di atas adalah lafaz (تعتدونها) dengan mentasydidkan huruf dal. Jumhur membaca sesuai dengan teks. Sementara Ibnu Katsir, Hamzah, al-Kisa'i, Abu 'Amer, Ibnu 'Asim dan Nafi' membaca ta'tadunaha (تعتدونها) dengan mentakhfifkan huruf dal. ${ }^{38}$ Perbedaan qira'at tersebut tidak menimbulkan perbedaan dalam menetapkan hukum, yakni istri yang diceraikan oleh suaminya tidak ada 'iddah baginya apabila belum digauli (disetebuhi) oleh suaminya yang harus disempurnaan bilangannya.

Contoh lain disebutkan dalam QS. al-Baqarah/2: 184 berikut:

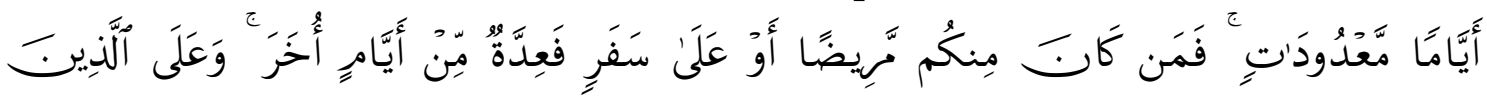

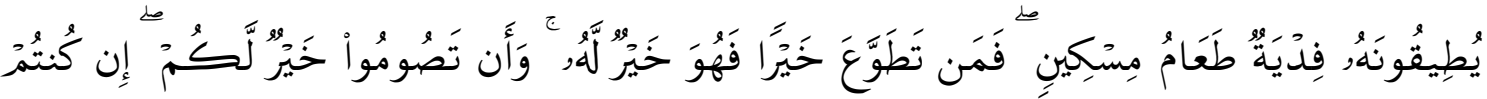
تَعَلَمُونَ

Terjemahnya:

(yaitu) dalam beberapa hari yang tertentu. Maka Barangsiapa diantara kamu ada yang

${ }^{37}$ Kementerian Agama RI, al-Qur'an dan Terjemahnya, h. 675.

${ }^{38}$ Muhammad 'Ali al-Sabuni, Rawai 'u al-Bayan Tafsir Ayat al-Ahkam min al-Qur'an, Juz II, h. 289. 
sakit atau dalam perjalanan (lalu ia berbuka), Maka (wajiblah baginya berpuasa) sebanyak hari yang ditinggalkan itu pada hari-hari yang lain. dan wajib bagi orangorang yang berat menjalankannya (jika mereka tidak berpuasa) membayar fidyah, (yaitu): memberi Makan seorang miskin. Barangsiapa yang dengan kerelaan hati mengerjakan kebajikan. Maka Itulah yang lebih baik baginya. dan berpuasa lebih baik bagimu jika kamu mengetahui. ${ }^{39}$

Ayat di atas menjelaskan bahwa orang sakit, musafir boleh berbuka puasa, tetapi wajib mengganti puasanya di luar bulan Ramadhan, begitu pula orang yang lanjut usia tidak mampu lagi berpuasa, maka dibolehkan tidak berpuasa, tetapi wajib mengganti dengan membayar fidyah kepada seorang miskin.

Dalam ayat di atas terdapat perberbedaan qira'at lafaz (يطيقونه). Jumhur membaca sesuai dengan teks (يطيقونه), sementara Ibnu 'Abbas membaca yuthawwaqunahu (يطوقونه) yakni dalam arti dibebankannya dengan mentasydidkan.40 Dan lafaz (فية طعام مسكين). Jumhur membaca sesuai dengan teks, sementara Nafi' dan Ibnu 'Amir membaca (فدية طعام مساكين) dalam bentuk jama' (مساكين) dan menyandarkan (مضاف) lafaz (فدية) kepada lafaz (طعام).41 yakni lafaz (فية) tidak bertanwin huruf terakhir karena mudhaf (sandar). Menurut kaidah bahasa Arab, apabila kata itu mudhaf (sandar) maka tidak boleh bertanwin, dan mudhaf ilaih (مضاف إليه) harus dikasrah. Seperti lafaz مضاف (طعام) dalam ayat ini boleh dikasrah huruf terakhir karena mudhaf ilaihi (إليعام) yakni disandari.

Selanjutnya lafaz (فمن تطّّ ع) Jumhur membaca dalam bentuk fi'il madhi, fa man tathawa'a dalam keadaan menasab huruf terakhir, sementara Hamzah dan al-Kisa'i membaca fa man tathawwa' (فمن تطوّع ع ( ف) ) dalam keadaan dijazam

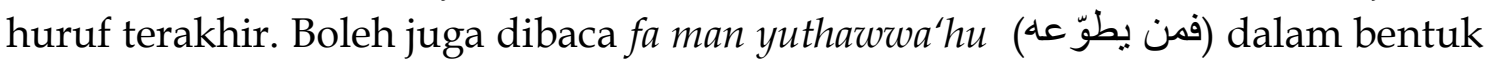
fi' il mudahari. 42

Perbedaan bacaan kalimat-kalimat tersebut yang boleh dibaca dengan dua versi bacaan, baik lafaz (من قبل أن تمسّو هنّ), kata (بطيقونه), lafaz (فدية طعام مسكين) maupun kata (فمن يطوّ ع) semuanya tidak menimbulkan pengubahan arti yang dikandungnya. Begitu pula halnya dalam masalah hukum yang dikandungnya tidak menimbulkan pengaruh terhadap perbedaan hukum yang diistinbatkan.

\section{KESIMPULAN}

Perbedaan qira'at ada yang menimbulkan pengaruh terhadap perbedaan hukum yang diistinbatkan dan ada yang tidak menimbulkan pengaruh terhadap perbedaan hukum yang ditimbulkan.

${ }^{39}$ Kementerian Agama RI, al-Qur'an dan Terjemahnya, h. 44.

${ }^{40} \mathrm{Abu}$ 'Abdillah Muhammad Ibnu Ahmad al-Qurtubi, al-Jami' li Ahkam al-Qur'an, Juz II, h. 267. Abu Ja 'far Ibnu Jarir al-Thabari, Jami ‘ al-Bayan fi Ta'wil al-Qur'an, Juz II, h. 112.

${ }^{41} \mathrm{Abu}$ 'Abdillah Muhammad Ibnu Ahmad al-Qurtubi, al-Jami' li Ahkam al-Qur'an, Juz II, h. 267.

${ }^{42} \mathrm{Abu}$ 'Abdillah Muhammad Ibnu Ahmad al-Qurtubi, al-Jami' li Ahkam al-Qur'an, Juz II, h. 270. 
1. Perbedaan qira'at yang berpengaruh terhadap perbedaan hukum yang diistinbatkan. Dalam QS. al-Baqarah/2: 222. Lafaz (يطهرن), dua versi bacaan yathhurna (يطهرن) dengan bacaan takhfif, dan (يطّة نطّرن) ) dengan bacaan tasydid. Bacaan pertama dengan (يطهرن) bahwa suami haram hukumnya menggauli (berjima') istrinya sebelum berhenti haidnya dan mandi. Sementara qira'at (يطّّمرن) dengan bacaan tasydid, halal menggauli istrinya apabila sudah berhenti haidnya meskipun belum mandi.

Dalam QS. al-Maidah/5: 6. Lafaz (وأرجلكم إلى الكعبين) dua versi qira'at (وأرجل) dinasabkan huruf lam, dan (وأرجلكم) dikasrahkan huruf lam. Apabila dibaca dengan bacaan pertama, maka dia ma'thuf dari lafaz ( فاغسلو اوجو هكم وأيدكم إلى () bahwa hukum mencuci kaki sampai kedua mata kaki wajib, sama hukum wajibnya mencuci wajah dan kedua tangan sampai kedua siku. Jika dibaca (وأرجلكم) dengan dikasrahkan huruf lam, maka hukum wajibnya menyapu kaki sampai kedua mata kaki (sepatu khuf) sebagaimana wajibnya menyapu sebahagian kepala.

Dalam QS. al-Nisa/4: 43. Lafaz (لامستم النسآء), dua versi qira'at (لامستم) dan (لمستم). Apabila dibaca dengan bentuk bacaan pertama, lafaz tersebut berarti bersentuhan dengan tangan (المس باليد). Jadi bersentuhan laki-laki dan perempuan yang bukan muhrim membatalkan wudhu.' Dan apabila dibaca dengan (لمسنم), lafaz tersebut diartikan dengan al-jima'( الجمآء) yakni bersetubuh, jadi tidak membatalkan wudhu', tetapi jika lafaz (المس) diartikan dengan (المس باليد) yang berarti menyentuh dengan tangan, maka bersentuhan laki-laki dan perempuan yang bukan muhrim membatalkan wudhu.'

2. Perbedaan qira'at yang tidak berpengaruh terhadap perbedaan hukum yang diistinbatkan. Dalam QS al- Ahzab/33: 49. Dalam ayat tersebut dua versi qira'at (من قبل أن تمسّو هنّ), dan (نن قبل إن تماسهن) dengan tambahan huruf alif. Dan lafaz (تعتدّونها), sesuai dengan teks dengan bacaan tasydid, huruf dal dan (تعتدونها) dengan bacaan takhfif.

Begitu pula dalam QS. al-Baqarah/2: 184. Dalam ayat tersebut dua versi

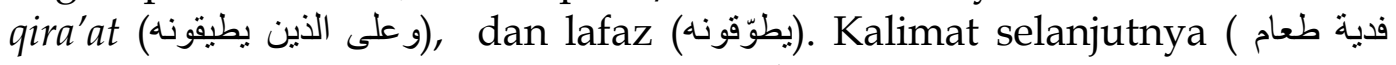
مسكين), sesuai dengan teks dan (فدية طعام مساكين), dalam bentuk jama' lafaz

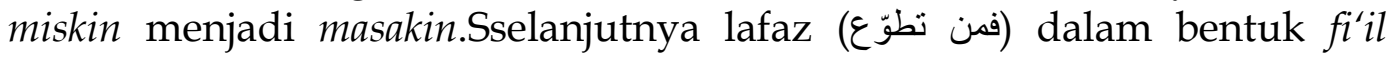
madhi, dan (فمن تطوّع) dengan menjazam huruf terakhir (mim) dan dibaca (فمن يطوّ عه) dengan bentuk fi'il mudhari'. 


\section{DAFTAR PUSTAKA}

'Atar, Nur al-Din, 'Ulum al-Qur'an al-Karim. Cet.VI, Damaskus: al-Sabal, 1996.

A.F., Hasanuddin. Anatomi al-Qur'an; Perbedaan Qira'at dan Pengaruhnya Terhadap Istinbath Hukum dalam al-Qur'an. Jakarta: PT. Raja Grafindo Persada, 1995.

Akaha, 'Abduh Zulfikar. Al-Qur'an dan Qira'at. Jakarta: Pustaka al-Husna, 1996. al-Jaziri, Ibn. Al-Nasyr fi al-Qira'at al-'Asyr, Juz I, Mesir: Dar al-Fikr, t.th.

al-Mawdudi, Abu al-A'la. The Meaning of The Qur'an. New Delhi: Maktabah alJama'ah E-Islami Hind, 1972.

al-Qattan, Manna Khalil. Mabahis fi 'Ulum al-Qur'an. Beyrut: Mansyurat al-'Asr al-Hadits, 1973.

al-Sabuni, Muhammad 'Ali al-Sabuni, al-Tibyan fi 'Ulum al-Qur'an. Cet. 1, Beyrut: Alim al-Kutub, t.th

------ . Rawai'i al-Bayan Tafsir Ayat al-Ahkam min al-Qur'an. Beyrut: 'Alim alKutub, 1986.

al-Salih al-Subhi. Mabahis fi 'Ulum al-Qur'an. Cet. VII, Dar al-'Ilm li al-Mayayin, 1988.

al-Suyuti, Jajal al-Din. Al-Itqan fi' Ulum al-Qur'an. Kairo: Dar al-Hadis, 2006.

al-Zarkasyi, Badr al-Din Muhammad. al-Burhan fi 'Ulum al-Qur'an. Mesir: 'Isa al-Babi al-Halabi, t.th.

al-Zarqani, Muhammad 'Abd al-'Azim. Manahil al-'Irfan fi 'Ulum al-Qur'an. Beyrut: Dar al-Fikr, 1988.

Diraz, Muhammad 'Abdullah. Madkal ila al-Qur'an al-Karim 'Aradun Tarikhiyun Maqarin. Cet.II. Kuwait: Dar al-Kalam, 1978.

Harun, Salman. Kaidah-Kaidah Tafsir: Bekal Mendasar Untuk Memahami Makna alQur'an dan Mengurangi Kesalahan Pemahaman. Cet I, Jakarta: QAF, 2017.

Mujahid, Ibn. Kitab al-Sab'at fi Qira'at. Mesir: Dar al-Ma'arif, t.th.

Syahir, 'Abd al-Sabur. Qira'at al-Qur'aniyah fi Dani 'Ilm al-Lughat al-Hadis. Kairo: Dar al-`Ilm, 1996. 